\title{
ABOUT AUTHORS
}

Aam Slamet Rusydiana is the head researcher at SMART Consulting. His research interests include Islamic banking, Islamic finance, quantitative and qualitative methods.

Ahmad Rodoni is the lecture at UIN Syarif Hidayatullah Jakarta. He also as a researcher on Islamic Management Studies.

Annisa Rindra Utami is master students at Economics Department at Agricultural Bogor University. Shee also as a researcher on Economics Studies.

Aris Setiawan is a researcher at Raoudho Berkah. His research interest include Islamic economics and finance.

Budi Harsanto is the lecture of Faculty of Economics and Business, Universitas Padjajaran. He also as a researcher on Islamic Finance Studies

Hj. Abdullah Abd Ghani is professor at Islamic Business School, Universiti Utara Malaysia. She also as a researcher on Islamic Economic Studies.

Ismawati Haribowo is the lecture at UIN Syarif Hidayatullah Jakarta. She finished master degree at Universitas Padjajaran. She also as a researcher on Accounting Studies.
Jaenal Effendi is a lecture at Agricultural Bogor University. He also as a researcher on Economics Studies.

Leis Suzanawaty is the lecture at UIN Syarif Hidayatullah Jakarta. She currentyly is Ph.D Students at Department of Management, Universitas Indonesia.

M Ashraf Al Haq is a Ph.D students at Islamic Business School, Universiti Utara Malaysia. He also as a researcher on Islamic Economic Studies.

M Shabri Abd Majid received his Sarjana Ekonomi (SE) from Syiah Kuala University, Indonesia, in 1995. He completed his Master of Economics $(\mathrm{MEc})$ and $\mathrm{PhD}$ in Financial Economics from the International Islamic University Malaysia (IIUM) in 1998 and 2005, respectively. His research interests include applied econometrics, Islamic economics, banking and finance.

Muhammad Kholifatul I.A. is a master students at Universitas Padjajaran. He also as a researcher on Islamic Finance Studies.

Nor Azlina binti Abd Wahab is a senior lecture at Islamic Business School, Universiti Utara Malaysia. She also as a researcher on Islamic Economic Studies. 
Nor Hayati Ahmad is professor at Islamic Business School, Universiti Utara Malaysia. She also as a researcher on Islamic Economic Studies.

Rahmatina A Kasri is a lecture at Department of Economics, Islamic Economics Program, Universitas Indonesia. She finished doctoral degree at Durham University, UK.

Raditya Sukmana is lecture at Islamic Economics Department, Airlangga University. He also as a researcher on Islamic economics and finance studies.

Said Zulhanizar is a banker from Bank of Aceh Syariah. He also as a researcher on Islamic Banking Studies.

Salman Al-Farisi is the junior researcher at SMART Consulting. His research interests is Islamic financial institution, Islamic economics, and Islamic banking.
Sari Suryaningtyas is a master student at Airlangga University. She also as a researcher on Islamic economics and finance studies.

Tahreem Noor Khan is the lecture at Al Yamamah University, Saudi Arabia. $\mathrm{He}$ also as a researcher on Islamic Economics Studies.

Yulianti is the lecture at UIN Syarif Hidayatullah Jakarta. She finished master degree at Universitas Padjajaran. She also as a researcher on Accounting Studies.

Yunizar is the lecture of Faculty of Economics and Business, Universitas Padjajaran. He also as a researcher on Islamic Finance Studies

Zuwesty Eka Putri is the lecture at UIN Syarif Hidayatullah Jakarta. She also as a researcher on Accounting Studies. 


\section{ARTICLES \& AUTHORS}

\section{Vol. 8 (1) January 2016}

\begin{tabular}{|c|c|c|c|}
\hline No & Name & Title & Note \\
\hline 1 & $\begin{array}{l}\text { M. Shabri Abd } \\
\text { Majid }\end{array}$ & $\begin{array}{l}\text { The Short-Run and Long- } \\
\text { Run Relationship in } \\
\text { Indonesian Islamic Stocks } \\
\text { Return }\end{array}$ & $\begin{array}{l}\text { Lecture of Syiah Kuala } \\
\text { University. Also as a researcher } \\
\text { on Islamic Economics and } \\
\text { Finance Studies }\end{array}$ \\
\hline 2 & $\begin{array}{l}\text { Aslam Mei Nur } \\
\text { Widigdo, Marimin, } \\
\text { Idqan Fahmi \& } \\
\text { Irfan Syauqi Beik }\end{array}$ & $\begin{array}{l}\text { Business Process } \\
\text { Reengineering of Funding } \\
\text { On Indonesia's Islamic } \\
\text { Banks }\end{array}$ & $\begin{array}{l}\text { Lecture of Agricultural Bogor } \\
\text { University. Also as a researcher } \\
\text { on Islamic Economics and } \\
\text { Finance Studies }\end{array}$ \\
\hline 3 & $\begin{array}{l}\text { M Nadratuzzaman } \\
\text { Hosen \& } \text { Rafika } \\
\text { Rahmawati }\end{array}$ & $\begin{array}{l}\text { Efficiency and Profitability } \\
\text { On Indonesian Islamic } \\
\text { Banking Industry }\end{array}$ & $\begin{array}{l}\text { Lecture of UIN Syarif } \\
\text { Hidayatullah Jakarta and lecture } \\
\text { of Universitas Islam } 45 \text { Bekasi. }\end{array}$ \\
\hline 4 & Tulus Suryanto & $\begin{array}{l}\text { Islamic Work Ethics and } \\
\text { Audit Opinions: Audit } \\
\text { Professionalism and } \\
\text { Dysfunctional Behavior as } \\
\text { Intervening Variables }\end{array}$ & $\begin{array}{l}\text { Lecture of IAIN Raden Intan } \\
\text { Lampung. Also as a researcher } \\
\text { on Islamic Accounting Studies }\end{array}$ \\
\hline
\end{tabular}

5 Sri Herianingrum Dual Monetary System Lecture of Airlangga \& Imronjana and Macroeconomic University. Also as a researcher Syapriatama Performance in Indonesia on Islamic Economics Studies

\begin{tabular}{|c|c|c|c|}
\hline 6 & $\begin{array}{l}\text { Ari Prasetyo \& Intan } \\
\text { Kusuma Pratiwi }\end{array}$ & $\begin{array}{l}\text { Islamic Business Ethics } \\
\text { Implementation in } \\
\text { Marketing Communication } \\
\text { of Hajj/Umrah Travel } \\
\text { Agency "Shafira Tour and } \\
\text { Travel" Surabaya }\end{array}$ & $\begin{array}{l}\text { Lecture of Airlangga } \\
\text { University. Also as a researcher } \\
\text { on Islamic Economics Studies }\end{array}$ \\
\hline 7 & Ernawati & $\begin{array}{l}\text { Risk of Profit Loss Sharing: } \\
\text { The Case of Indonesia }\end{array}$ & $\begin{array}{l}\text { Lectures of Halu Oleo } \\
\text { University. Also as a researcher } \\
\text { on Islamic Economics Studies }\end{array}$ \\
\hline 8 & $\begin{array}{l}\text { Nurul Huda, } \\
\text { Nova Rini, Desti } \\
\text { Anggraini, Khamim } \\
\text { Hudori \& } \text { Yosi } \\
\text { Mardoni }\end{array}$ & $\begin{array}{l}\text { The Development of } \\
\text { Human Resources in } \\
\text { Islamic Financial Industries } \\
\text { From Economic and Islamic } \\
\text { Financial Graduates }\end{array}$ & $\begin{array}{l}\text { Lecturer at University of } \\
\text { Yarsi, STIE Muhammadiyah } \\
\text { Jakarta, Universitas Indonesia, } \\
\text { and Open University of } \\
\text { Indonesia }\end{array}$ \\
\hline
\end{tabular}




\begin{tabular}{|c|c|c|c|}
\hline 9 & $\begin{array}{l}\text { Andi Reni \& Nor } \\
\text { Hayati Ahmad }\end{array}$ & $\begin{array}{l}\text { Application of Theory } \\
\text { Reasoned Action in } \\
\text { Intention to Use Islamic } \\
\text { Banking in Indonesia }\end{array}$ & $\begin{array}{l}\text { Lecture of Universitas } \\
\text { Hasanuddin and Lecture } \\
\text { of Colloge of Business, } \\
\text { Universiti Utara Malaysia }\end{array}$ \\
\hline 10 & $\begin{array}{l}\text { Farra Munna } \\
\text { Harun, Bayu Taufiq } \\
\text { Possumah, } \quad \text { M } \\
\text { Hakimin bin Moh } \\
\text { Shaifai \& Abd. } \\
\text { Halim Mohd. Noor }\end{array}$ & $\begin{array}{l}\text { Issues and Economic } \\
\text { Role of Waqf in Higher } \\
\text { Education Institution: } \\
\text { Malaysian Experience }\end{array}$ & $\begin{array}{lr}\text { Lecture of } & \text { Universiti } \\
\text { Kebangsaan } & \text { Malaysia, } \\
\text { Universiti } & \text { Malaysia } \\
\text { Trengganu, and } & \text { Universiti } \\
\text { Teknologi MARA } & \end{array}$ \\
\hline
\end{tabular}

Vol. 8 (2), July 2016

\begin{tabular}{|c|c|c|c|}
\hline No & Name & Title & Note \\
\hline 1 & Rahmatina A Kasri & $\begin{array}{l}\text { Effectiveness of Zakah } \\
\text { Targeting in Alleviating } \\
\text { Poverty in Indonesia }\end{array}$ & $\begin{array}{l}\text { Lecture of Universitas } \\
\text { Indonesia. Also as a } \\
\text { researcher on economics and } \\
\text { finance studies }\end{array}$ \\
\hline 2 & $\begin{array}{l}\text { Raditya Sukmana, } \\
\text { Sari Suryaningtyas }\end{array}$ & $\begin{array}{l}\text { Determinants of Liquidity } \\
\text { Risk in Indonesian Islamic } \\
\text { and Conventional Banks }\end{array}$ & $\begin{array}{l}\text { Lecture of University of } \\
\text { Airlangga. Also as a researcher } \\
\text { on Islamic Economics and } \\
\text { Finance Studies }\end{array}$ \\
\hline 3 & $\begin{array}{ll}\text { M Shabri } & \text { Abd } \\
\text { Majid, } & \text { Said } \\
\text { Zulhanizar } & \end{array}$ & 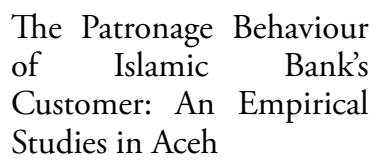 & $\begin{array}{l}\text { Lecture of Syiah Kuala } \\
\text { University. Alsoasa researcher } \\
\text { on Islamic Economics and } \\
\text { Finance Studies }\end{array}$ \\
\hline 4 & $\begin{array}{l}\text { Aam Slamet } \\
\text { Rusydiana, Salman } \\
\text { Al-Farisi }\end{array}$ & $\begin{array}{l}\text { The Efficiency of Zakah } \\
\text { Institutions Using Data } \\
\text { Development Analysis }\end{array}$ & $\begin{array}{l}\text { Researcher at SMART } \\
\text { Consulting with research } \\
\text { interests on Islamic banking, } \\
\text { Islamic finance, and Islamic } \\
\text { economics studies. }\end{array}$ \\
\hline 5 & $\begin{array}{l}\text { Jaenal } \\
\text { Annisa } \\
\text { Utami }\end{array}$ & $\begin{array}{l}\text { The Effect of Social } \\
\text { Capital on Customer's } \\
\text { Repayment Rate at Islamic } \\
\text { Microfinance Institution }\end{array}$ & $\begin{array}{l}\text { Lecture of Bogor Agricultural } \\
\text { University. Also as a researcher } \\
\text { on Islamic Economics and } \\
\text { Finance Studies }\end{array}$ \\
\hline 6 & $\begin{array}{l}\text { M u h a m m a d } \\
\text { Kholifatul I } \\
\text { Ardiansyah, Yunizar, } \\
\text { Budi Harsanto }\end{array}$ & $\begin{array}{l}\text { Sharia Compliant } \\
\text { E-Commerce Models and } \\
\text { Customer Trust }\end{array}$ & $\begin{array}{l}\text { Lecture at University of } \\
\text { Padjajaran Researcher on } \\
\text { Islamic Economics and } \\
\text { Finance Studies }\end{array}$ \\
\hline
\end{tabular}




\begin{tabular}{|c|c|c|c|}
\hline 7 & $\begin{array}{l}\text { Ahmad Rodoni, } \\
\text { Aris Setiawan }\end{array}$ & $\begin{array}{l}\text { Risk and Return: Bonds } \\
\text { and Sukuk in Indonesia }\end{array}$ & $\begin{array}{l}\text { Lecture at UIN } \begin{array}{r}\text { Syarif } \\
\text { Hidayatullah } \\
\text { Researcher on Jakarta. }\end{array} \text { Islamic } \\
\text { Economics and Finance Studies }\end{array}$ \\
\hline 8 & $\begin{array}{l}\text { M Ashraf Al Haq, } \\
\text { Nor Azlina bt Abd } \\
\text { Wahab, Hj Abdullah } \\
\text { Abd Ghani, Nor } \\
\text { Hayati Ahmad }\end{array}$ & $\begin{array}{l}\text { Islamic Prayer, Spirituality } \\
\text { and Productivity: An } \\
\text { Exploratory Conceptual } \\
\text { Analysis }\end{array}$ & $\begin{array}{l}\text { Lecture of Islamic Business } \\
\text { School, Universiti Utara } \\
\text { Malaysia. Also as a researcher } \\
\text { on Islamic Banking studies }\end{array}$ \\
\hline 9 & $\begin{array}{l}\text { Tahreem } \\
\text { Khan }\end{array}$ & $\begin{array}{lr}\text { Islamic } & \text { Banks Service } \\
\text { Quality: } & \text { Conceptual } \\
\text { Model } & \end{array}$ & $\begin{array}{l}\text { Lecture of Al Yamamah } \\
\text { University, Saudi Arabia. } \\
\text { Also as a researcher on } \\
\text { Islamic Economics and } \\
\text { Finance Studies }\end{array}$ \\
\hline 10 & $\begin{array}{l}\text { Yulianti, } \\
\text { S u z a n a w a t y, } \\
\text { Zuwesty Eka Putri, } \\
\text { Ismawati Haribowo }\end{array}$ & $\begin{array}{l}\text { Determinants of The } \\
\text { Corporate Environmental } \\
\text { Disclosure: Study on } \\
\text { Jakarta Islamic Index }\end{array}$ & $\begin{array}{l}\text { Lecture of } \\
\text { Hidayatullah State Islamic } \\
\text { University Jakarta. Also } \\
\text { as a researcher on Islamic } \\
\text { Accounting Studies }\end{array}$ \\
\hline
\end{tabular}




\section{AUTHORS INDEX}

Aam Slamet Rusydiana

Abd. Halim Mohd. Noor

Ahmad Rodoni

Andi Reni

Annisa Rindra Utami

Ari Prasetyo

Aris Setiawan

Aslam Mei Nur Widigdo

Bayu Taufiq Possumah

Budi Harsanto

Desti Anggraini

Ernawati

Farra Munna Harun

Hj. Abdullah Abd Ghani

Idqan Fahmi

Imronjana Syapriatama

Intan Kusuma Pratiwi

Irfan Syauqi Beik

Ismawati Haribowo

Jaenal Effendi

Khamim Hudori

Leis Suzanawaty
Marimin

M. Ashraf Al Haq

M Hakimin bin Moh Shaifai

M Nadratuzzaman Hosen

M. Shabri Abd. Majid

Muhammad Kholifatul I. Ardiansyah

Nor Azlina bt Abd Wahab

Nor Hayati Ahmad

Nova Rini

Nurul Huda

Raditya Sukmana

Rafika Rahmawati

Rahmatina A Kasri

Said Zulhanizar

Salman Al Farisi

Sari Suryaningtyas

Sri Herianingrum

Tahreem Noor Khan

Tulus Suryanto

Yosi Mardoni

Yulianti

Yunizar

Zuwesty Eka Putri 


\section{SUBJECT INDEX}

\begin{tabular}{ll} 
Alignment Index & Macroeconomics \\
Audit Professionalism & Malaysia \\
Auditor' Opinions & Marketing Communication \\
Bond & Money Supply \\
Business Process Reengineering & Mudharaba \\
Conventional Banks & Murabaha \\
Corporate Environmental Disclosure & Musharaka \\
Customer's Repayment Rate & Patronage Behaviour \\
Customer Trust & Poverty \\
Data Envelopment Analysis & Poverty Alleviation \\
Dual monetary policy & Povery Index \\
Dysfunctional Behavior & Productivity \\
ECM & Profitability \\
E-Commerce & Profit-loss sharing \\
Efficiency & Return \\
Exchange Rate & Risk \\
Exploratory study & Risk averse \\
Higher Education Institution & Service Quality \\
Intention & SIFAT \\
Islamic Bank's Customer & Social Capital \\
Islamic Banking & Sharia Compliant \\
Islamic Business Ethics & Spirituality \\
Islamic Economics & Stochastic Frontier Analysis \\
Islamic Microfinance Institution & Sukuk \\
Islamic Prayer & Theory Reasoned Action \\
Islamic Stock Market & Tracer Study \\
Islamic Work Ethics & VAR \\
Issues & Value Stream Mapping \\
Jakarta Islamic Index & Waqf \\
Liquidity Risk & Zakah \\
\hline
\end{tabular}




\section{COPYRIGHT TRANSFER AGREEMENT}

Authors submitting a manuscript do so on the understanding that if accepted for publication, copyright of the article shall be assigned to Al-Iqtishad: Jurnal Ilmu Ekonomi Syariah (Journal of Islamic Economics) as publisher of this journal.

Copyright encompasses exclusive rights to reproduce and deliver the article in all forms and media, including reprints, photographs, microfilms and any other similar reproductions, as well as translations. The reproduction of any part of this journal, its storage in databases and its transmission by any forms or media, such as electronic, electrostatic and mechanical copies, photocopies, recordings, magnetic media, etc., will be allowed only with a written permission from Al-Iqtishad: Jurnal Ilmu Ekonomi Syariah (Journal of Islamic Economics).

Al-Iqtishad: Jurnal Ilmu Ekonomi Syariah (Journal of Islamic Economics), Editors, and International Advisory Editorial Board make every effort to ensure that no wrong or misleading data, opinions or statements be published in the journal. In any way, the contents of the articles and advertisements published in Al-Iqtishad: Jurnal Ilmu Ekonomi Syariah (Journal of Islamic Economics) are sole and exclusive responsibility of their respective authors and advertisers.

The copyright form should be filled with respect to article and be signed originally and sent to the Editorial Office in the form of original mail, or scanned document file (softcopy) to:

\section{Nur Rianto Al Arif}

Editorial Office Al-Iqtishad

Faculty of Shariah and Law

Syarif Hidayatullah State Islamic University Jakarta

Jl Ir H Juanda No 95, Ciputat, South Tangerang, Banten, Indonesia -15412-

Phone (+6221) 74711537, Fax. (+6221) 7491821

Website: www.journal.uinjkt.ac.id/index.php/iqtishad;

Email: iqtishad@uinjkt.ac.id; editor.iqtishad@yahoo.com 


\section{Copyright Transfer Agreement}

Name of Principal Authors:

Address of Principal Authors:

Tel/Fax:

E-mail:

Author(s) Name:

Manuscript Title:

Date Received:

1. I/We submit to the Al-Iqtishad: Jurnal Ilmu Ekonomi Syariah (Journal of Islamic Economics). I/We certify that the work reported here has not been published before and contains no materials the publication of which would violate any copyright or other personal or proprietary right of any person or entity.

2. I/We hereby agree to transfer to Al-Iqtishad: Jurnal Ilmu Ekonomi Syariab (Journal of Islamic Economics)/ Publisher for the copyright of the above named manuscript.

3. I/We reserve the following: (1) All proprietary rights other than copyright such as patent rights. (2) The right to use all or part of this article in future works of our own such as in books and lectures. Print or Type Name and Title of Author.

Date:

Signature

(When there is more than one author, only the first author that sign this copyright) 


\section{ACKNOWLEDGMENT TO REVIEWERS IN THIS ISSUE}

Contribution from the following Reviewers in this issue was very appreciated for their valuable review comments:

Ahmad Tholabi
Ake Wihadanto
Asep Saepudin Jahar
Ashraf Md Hashim
Atiquzzafar Khan
Bayu Taufiq Posumah
Euis Amalia
Hendri Tanjung
M Amir Kia
M. Nadratuzaman Hosen
M. Kabir Hassan
Mehmet Asutay
Mustafa E Nasution
Mohammad Hudaib
Mokhamad Anwar
Monzer Khaf
Muhammad Iqbal Anjum
Ratno Purnomo
Roszaini Haniffa
Subandriah
Unggul Purwohedi

(UIN Syarif Hidayatullah Jakarta - Indonesia)

(Open University - Indonesia)

(UIN Syarif Hidayatullah Jakarta - Indonesia)

(ISRA - Malaysia)

(International Islamic University Islamabad - Pakistan)

(Universiti Malaysia Trengganu - Malaysia)

(UIN Syarif Hidayatullah Jakarta - Indonesia)

(University of Ibn Khaldun - Indonesia)

(Utah Valley University - USA)

(UIN Syarif Hidayatullah Jakarta - Indonesia)

(University of New Orleans - USA)

(Durham University Business School - UK)

(University of Indonesia - Indonesia)

(Adam Smith Business School, Glasgow Univ., UK)

(Universitas Padjajaran - Indonesia)

(Qatar Faculty of Islamic Studies, Qatar)

(International Islamic University Islamabad - Pakistan)

(University of General Soedirman - Indonesia)

(Heriot Watt University, United Kingdom)

(Ministry of Religious Affairs - Indonesia)

(Universitas Negeri Jakarta - Indonesia) 


\section{AL-IQTISHAD \\ Jurnal IImu Ekonomi Syariah (Journal of Islamic Economics)}

\section{GUIDANCE FOR WRITING IN Journal of Al-Iqtishad}

1. The manuscripts represent academic research in Islamic economics and Finance discipline.

2. Upon the publication of the manuscript, the author should provide a letter states that the manuscripts have never been, or under consideration to be, published in other journal publications.

3. Structure of the manuscripts

a. Title. The title should be short, clear, and informative, but does not exceed 9 words.

b. Author's names and institutions. The author's names should be accompanied by the author's institutions and email addresses, without any academic titles and/or job title.

c. Abstract and keywords. The abstract should be less than 150 words. The key words should be 2 to 5 phrases.

d. Introduction. This section explains the backround of the study, and aims of the manuscripts. It should be written without numbers and/or pointers.

e. Literature Review. This section explains the theoretical framework that used on this research, a review on the previous research in the area.

f. Methods. This section describes the tools of analysis along with the data and their sources.

g. Discussion. This section explains the results of the study.

h. Conclusions. This section concludes and provides policy implications, if any, of the study.

i. References. This section lists only the papers, books, or other types of publications referred in the manuscript.

4. The authors should provide an index of subject, namely the specific terms in the manuscript. The authors should also provide the index of authors, namely the key authors of papers referred in the manuscript. Please write the family name followed by the given name.

5. Estimation result from a software package is not allowed to be directly presented in the paper. They should be presented in equations with the appropriate estimation results.

6. Table format should contain only heading and contents. Please provide the top and bottom lines, along with the line(s) that separate the heading and the contents. Example: 
Table 1. The Growth of Third Party Fund, Financing and Asset (Billion rupiah)

\begin{tabular}{lllllll}
\hline & $\mathbf{2 0 0 9}$ & $\mathbf{2 0 1 0}$ & $\mathbf{2 0 1 1}$ & $\mathbf{2 0 1 2}$ & $\mathbf{2 0 1 3}$ & 2014* $^{*}$ \\
\hline Fundraising & 52.271 & 76.036 & 115.415 & 147.512 & 174.018 & 186.608 \\
Financing & 46.886 & 68.181 & 102.655 & 147.505 & 179.284 & 187.886 \\
Asset & 66.090 & 97.519 & 145.467 & 195.018 & 229.557 & 244.197 \\
\hline
\end{tabular}

Source: Islamic banking statistics, Bank of Indonesia

7. Acknowledgment, if any, should be written as the foot-note of the manuscript's title.

8. The manuscript is prepared in a quarto paper, single-sided, and double-space format. A new paragraph should start 5 characters from the left margin, using 12-size, times-newromans font type.

9. The manuscript is written in proper English, either British or American English, but not the combination of both, except for special editions.

10. The manuscript should be in no less than 25 pages long.

11. The top and bottom margins are 1 inch.

12. The title is written using capital letters of 14 font size, centre position.

13. Sub titles are written using capital letters, started from the left margin.

14. Sub of sub titles are written using capital letters only at the beginning of each word except for connecting words. They should be started from the left margin.

15. References should be those of the last ten years publication, unless they are key references.

16. Citation in the text body should be written using the family name and years of publication. Example:
a. Hill (2001) suggests that the objective of depreciation ....
b. According to Kotter (1867), intra industry trade can be ...
c. Wagner (in McCain, 1982) states that ...
d. The definition of flypaper effect is ... (Wagner, 1976).

17. Tables and figures should be presented as follows:

a. The name of tables and figures should follow a numbering system (Arabic numbering system). The names of the tables and figures are on the top and bottom parts of the tables, respectively.

b. The tables and figures should provide the source of information, if any, at the bottom part of both.

18. References should be written in alphabetical order, without any number. They should be written using the following criteria:

a. For books, the format should follow the following example:

Al Arif, M. N. R. 2015. Pemasaran Stratejik Pada Asuransi Syariah. Jakarta: Gramata.

b. For papers that are part of a book, the format should follow the following example:

Bahl, R. 2000. How to Design a Fiscal Decentralization. in Sahid, Y. (eds.), Local Dynamics in an Era of Globalization, 25-26, London: Oxford University Press. 
c. For journal/magazine papers, the format should follow the following example:

Al Arif, M. N. R. 2012. Efek Multiplier Wakaf Uang dan Pengaruhnya Terhadap Program Pengentasan Kemiskinan. Jurnal Asy-Syir'ah, Vol. 46 (1), January 2012, hlm. $10-12$.

d. For internet references, the format should follow the following example:

Kharlie, Ahmad Tholabi. 2006. "Formalisasi Syariat Islam, Mengapa Tidak?", http//www.ahmadtholabi.wordpress.com, accesed on 17 Maret 2014

e. For magazine, the format should follow the following example:

Asa, Syu'bah. 2004 "Pengantin Darah", dalam Tempo, No. 30/XXX111/20, 20 September 2004

19. Transliteration guidance (from Arabic to latin)

\begin{tabular}{|c|c|c|}
\hline \multicolumn{3}{|c|}{ Consonant } \\
\hline$(1)=a$ & $(j)=\mathrm{z}$ & (ق) $=\mathrm{q}$ \\
\hline = b & = s (س) = & (s) $=\mathrm{k}$ \\
\hline (ت) $=\mathrm{t}$ & = sy & (ل) $=1$ \\
\hline$(ث)=$ ts & (ص) =sh & $(\rho)=m$ \\
\hline (ج) = j & (ض) = dh & (ن) $=\mathrm{n}$ \\
\hline$(\tau)=\underline{\mathrm{h}}$ & $(b)=$ th & $(g)=w$ \\
\hline$(\dot{\tau})=\mathrm{kh}$ & $(\dot{b})=\mathrm{zh}$ & $(ه)=h$ \\
\hline$(د)=d$ & $(\varepsilon)=$ ' & $(s)=$ ' \\
\hline$(\dot{\jmath})=\mathrm{dz}$ & $(\dot{\varepsilon})=\mathrm{gh}$ & (ي) =y \\
\hline$(\jmath)=r$ & (ف) =f & $(\ddot{a})=\underline{\mathrm{t}}$ \\
\hline
\end{tabular}

\begin{tabular}{|c|c|}
\hline Short Vocal & Long Vocal \\
\hline$-=\mathrm{a}$ & $(1-)=\hat{\mathrm{a}}$ \\
\hline$-\mathrm{i}$ & $(\varsigma-)=\hat{\mathrm{i}}$ \\
\hline$-\mathrm{u}$ & $(\mathrm{g}-)=\hat{\mathrm{u}}$ \\
\hline
\end{tabular}

\begin{tabular}{|c|c|}
\hline Diftong & Pembauran \\
\hline (أو) = aw & (ال) = al \\
\hline \multirow[t]{2}{*}{ (أي) = ay } & (الش) al-sy \\
\hline & (وال) = wa al- \\
\hline
\end{tabular}


20. The manuscript in microsoft word should be sent to iqtishad@uinjkt.ac.id or through online submission at:

http://journal.uinjkt.ac.id/index.php/iqtishad/user/register

21. A brief $\mathrm{CV}$ that records full name, academic title, institution, telephone, fax and mobile number should accompany the manuscript.

22. The decision of the manuscript are:
a. Accepted, or
b. Accepted with minor revision, or
c. Accepted with major revision, or
d. Rejected.

23. Upon the publication of the manuscript in the journal, the author will receive a publication proof number and 3 off-prints.

24. Further information about the journal can be seen at http://journal.uinjkt.ac.id/index. php/iqtishad 